\title{
Szakmai beszámoló a VII. Magyar Evészavar Kongresszusról
}

Budapest, 2018. szeptember 14-15.

A Magyar Pszichiátriai Társaság Evészavar Szekciója 2005-ben alakult meg, és egy évvel később, 2006-ban már megszervezte az I. Magyar Evészavar Kongresszust. A kétévente megtartott kongresszus háromszor volt Budapesten, majd Pécs és Debrecen volt a helyszín. Ezután a Szekció úgy döntött, hogy a további kongresszusok Budapesten lesznek.

A kongresszust a Magyar Pszichiátriai Társaság Evészavar Szekciójának alapítói, Pászthy Bea és Túry Ferenc nyitották meg, köszöntve a résztvevőket.

Az evészavarok jelentőségét az adja, hogy gyakori, általában fiatal korban, gyermekeknél, serdülőknél, fiatal felnőtteknél kezdődő betegségekről van szó, amelyek nagy szenvedéssel és sokféle - nemritkán irreverzibilis vagy halálos - szövődménnyel járnak, megnehezítik a társas múködést, a továbbtanulást és a munkavégzést, jelentős a pszichiátriai komorbiditásuk, és akár krónikussá is válhatnak. Így nemcsak a szakemberek részéról mutatkozik nagy érdeklődés az evészavarok iránt, hanem a laikusok körében és a médiában is népszerú témák ezek.

A kétnapos kongresszuson összesen 25 tudományos programra került sor: 8 plenáris előadásra, 2 szekcióban 13 szabad előadásra, 2 múhelyre, egy-egy plenáris vitára és kerekasztal-beszélgetésre.

Mint az előző kongresszusokon, most is egy meghívott külföldi szakember angol nyelvú plenáris előadásával kezdődött a tudományos program. Gerard J. Butcher (Trinity College, Dublin), aki már többször járt Magyarországon, és sokat segített eddig is az evészavarokkal foglalkozó fiatalabb magyar kollégáknak, az evészavarok kezelésében alkalmazható újabb technológiákat és innovációkat mutatta be. Bár egyre több lehetőséget nyújtanak az internetes és mobiltelefonos applikációk, ennek megvannak a kockázatai is, mivel az ezen médiumok által nagy számban elérhető módszerek közül van számos olyan, amely hatástalan vagy egyenesen káros. A szakemberek számára is kihívást jelent kiválasztani a megfelelő applikációkat és jó irányba terelni az érdeklődő pácienseket. Innovatív kutatás terepe az internet és a mobiltelefonos alkalmazás világa, ám az előadó szerint még nem sikerült megtalálni az optimális megoldást.

A második plenáris előadást Forgács Attila (társszerző: Csíkos Tímea) tartotta az ízpreferenciákról, az ízaverziókról és az ételfóbiákról. A szerző már a korábbi evészavar-kongresszusokon is nagyon sikeres plenáris előadásokat tartott. A megtárgyalt jelenségek viszonylag kevéssé ismertek, de 
meglepően sok tényezővel vannak kapcsolatban: evolúciós, genetikai, családdinamikai, szociálpszichológiai, környezetpszichológiai, kulturális és gazdasági háttér egyaránt lehetséges. A jelenségeket a szerző érdekes saját vizsgálati eredményekkel illusztrálta, és terápiás lehetőségekról is szó volt az előadásában. A szerző egyik saját eredménye, hogy ugyanazt a csapvizet ásványvízként kétszer drágábban lehet eladni, ha figyelemfelkeltő nevet adunk neki és vonzó a csomagolása.

A plenáris előadások után a szabad elóadásokkal folytatódott a kongreszszus. A 2 szekcióban 14 előadás hangzott el. Az „Elméleti megfontolások” címú szekcióban megtudhattuk, hogyan változott a testtel való elégedettség és az izomdiszmorfia egy évtized alatt Magyarországon, és hogyan van jelen az orthorexia nervosa az edzőterembe járók és a léböjttáborok résztvevői között, illetve milyen kapcsolat van az orthorexia nervosa és a kényszerbetegség között. Ebben a szekcióban még előadások hangzottak el egy testképet mérő háromdimenziós számítógépes modellező és grafikai programról, ennek alkalmazásának előzetes eredményeiről, a médiahatás és az evési attitúdök, valamint a vallás és az evészavarok kapcsolatáról, majd arról, hogyan jelentkeznek és hogyan kezelhetők az evészavarok a koragyermekkorban.

Ahogyan az Evészavarok Európai Tanácsának Kongresszusán, a Magyar Evészavar Kongresszuson is van plenáris vita, amelynek keretében homlokegyenest ellentétes állításokról érvelnek az előadók, majd a közönség folytatja a vitát. A felvetett tézis ezúttal az volt, hogy az ún. testpozitív programok segítik az evészavarok megelőzését. A két előadó, Csabai Márta és Csenki Laura rövid előadása után a közönség körében heves, hosszas és változatos vita bontakozott ki. A végső szavazás alapján a jelenlevők 2/3-a az „igen”, 1/3-a a „nem” mellett szavazott.

A délután folyamán két múhely közül lehetett választani. Ábrahám Ildikó, Csenki Laura, Pászthy Bea "Agresszió - regresszió - progresszió az evészavaros betegek terápiájában" címmel tartott múhelyt. Az evészavarok folyamatában bárhol jelen lehet az agresszió, a betegség kialakulásában, a tünetekben és a terápiás kapcsolatban is. A felismerést nehezíti, hogy legtöbbször nem nyílt formában fejeződik ki, hanem a passzív agresszió formájában. Az agresszió azonban az evészavaros betegek kezelésével foglalkozó szakemberek részéról is megnyilvánulhat. Konkrét példák megvitatása mentén folyt a múhely, interaktív és gyakorlatorientált jelleggel.

Túry Ferenc az evészavarok családterápiájáról tartotta múhelyét. A család messzemenően befolyásolja az evészavarok kialakulását, fennmaradását és gyógyulását. Így a családterápia az elsőként választandó módszer a családjukkal együtt élő evészavaros fiatalok kezelésében. Múhibának tekinthető, ha az ilyen családban élő serdülő anorexiás páciensnél nem alkal- 
mazunk családterápiát, vagy nem küldjük tovább családterápiára. Szó volt az evészavarosok családi rendszerében megfigyelhető jellegzetességekról és a családlátogatás jelentőségéről. Az elmondottakat az előadó terápiás esetekkel illusztrálta.

A tudományos program után az első nap estéjén a 20. emelet együttes koncertjén kapcsolódhattak ki a kongresszus résztvevói. A músor amerikai tradicionális énekek (Oh when the saints; Down by the Riverside; Baby please don't go), egy macedón népdal (Sto imala) és két moldvai csángó dal (Fáj a szívem; Kerek a szőlő levele) feldolgozásaiból állt. Az együttes neve (20. emelet együttes) arra utal, hogy a zenészek a Semmelweis Egyetem Magatartástudományi Intézetéhez kötődnek. Bóna Enikő fuvolán, Túry Ferenc citerán, Leindler Milán cajónon játszott.

A kongresszus 2. napja is plenáris előadásokkal kezdődött. Szalkay Krisztina korai evésregulációs zavarokról tartott előadása azért volt nagyon hasznos, mivel a résztvevők nagy része serdülőkkel és felnőttekkel foglalkozik. Ezután Pászthy Bea az evészavaros gyermekek és serdülők kezelésének modern irányelveit, Túry Ferenc pedig az evészavaros felnőttek kezelésének irányelveit ismertette.

A szabad előadások „Klinikai vonatkozások” címú szekciójában szó volt az elhízással élóknek az egészségügyben szerzett káros élményeiról (negatív diszkrimináció, stigmatizáció), az evészavarok nőgyógyászati vonatkozásairól, a szülői bánásmód hatásáról, a múvészetterápiás lehetőségekről, a belgyógyász-pszichiáter liaison szerepéről, valamint a viselkedésterápia hatékonyságáról a testsúlycsökkentésben.

A délutáni plenáris előadások a sport és az evészavarok kapcsolatáról szóltak. Nagyon érdekes volt az olimpikon-gyermekgyógyász Gyarmati Andreával folytatott interjú. A saját evészavaráról beszélt, amiről könyvet is írt. Az evészavar mindenkire lecsaphat, még egy ilyen rendkívül sikeres emberre is. Titokban küzdött évtizedekig tartó problémájával, a szégyen sokáig gátolta abban, hogy segítséget kérjen.

Zárásként két, családterápiával kezelt evészavaros páciens szüleivel folyt a plenáris kerekasztal-beszélgetés. Mindkét beteg igen súlyos állapotban volt, osztályos felvételre, szondatáplálásra kényszerült. A négy szülő őszinte, hiteles beszámolója a betegségalakulás részleteiról plasztikus képet rajzolt az evészavarok sokszínúségéról, a velük való megbirkózás nehézségeiról.

A kongresszuson elsősorban pszichiáterek, gyermekpszichiáterek, klinikai szakpszichológusok, dietetikusok, gyermekgyógyászok, belgyógyászok és gasztroenterológusok vettek részt. A korábbiakhoz képest felülreprezentáltak voltak a háziorvosok. Vélhetően a korábbinál magasabb részvételi díj miatt most kevesebb egyetemi hallgató és PhD-hallgató jött el. 
Összességében elmondható, hogy a VII. Magyar Evészavar Kongresszus minden szempontból magas színvonalú volt. A helyszín, a Radisson Blu Béke Hotel optimális helyszínnek bizonyult. A minden részletében profeszszionális szervezés a Convention Budapest Kft. érdeme.

Szabó Pál

E-mail: dr.szabopal@gmail.com 